\section{Hybrid hydrogen-battery systems for renewable off-grid telecom power}

\author{
D Scamman, M Newborough*, H Bustamante
}

ITM Power

\begin{abstract}
Off-grid hybrid systems, based on the integration of hydrogen technologies (electrolysers, hydrogen stores and fuel cells) with battery and wind/solar power technologies, are proposed for satisfying the continuous power demands of telecom remote base stations. A model was developed to investigate the preferred role for electrolytic hydrogen within a hybrid system; the analysis focused on powering a $1 \mathrm{~kW}$ telecom load in three locations of distinct wind and solar resource availability. When compared with otherwise equivalent off-grid renewable energy systems employing only battery energy storage, the results show that the integration of a $1 \mathrm{~kW}$ fuel cell and a $1.6 \mathrm{~kW}$ electrolyser at each location is sufficient, in combination with a hydrogen storage capacity of between 13 and $31 \mathrm{~kg}$, to reduce the required battery capacity by $54-77 \%$, to increase the minimum state-of-charge from $37-55 \%$ to $>81.5 \%$ year-round despite considerable seasonal variation in supply, and to reduce the amount of wasted renewable power by 55$79 \%$. For the growing telecom sector, the proposed hybrid system provides a 'green' solution, which is preferable to shipping hydrogen or diesel to remote base stations.
\end{abstract}

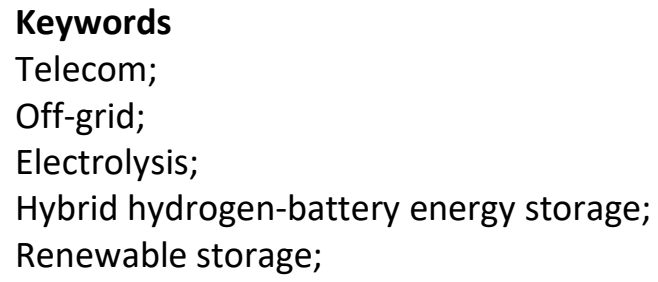

\title{
Highlights
}

- Remote telecom base stations require continuous power from variable renewables

- Renewable energy systems require energy storage to manage large supply fluctuations

- Batteries exhibit short lifetimes in renewable energy systems

- Integrating hydrogen energy facilitates close regulation of battery state-of-charge

- Hybrid hydrogen-battery systems provide a more reliable solution for off-grid power 


\section{Introduction}

The world faces a revolution in energy systems as it seeks to satisfy a growing global energy demand from an increasing population while dramatically reducing greenhouse gas emissions. In some regions and some applications, off-grid energy systems powered by renewables could contribute to the 2050 goal of cutting carbon emissions by $\geq 80 \%$ relative to 1990 . Such systems gradually become more affordable as manufacturing production rates increase. For example the IEA indicates that solar photovoltaic power sources could overtake coal power sources by 2050 by making a $27 \%$ contribution to the total supply, which when considered in conjunction with hydro, wind and biomass the total renewables contribution could amount to 79\% [1]. In Asia, Africa and the Middle East, plentiful resources and a lack of existing infrastructure could allow many developing countries to apply off-grid systems for decentralised power. For example, sub-Saharan Africa's population is expected to double to 1.75 billion by 2040 with energy demand increasing by $80 \%$, but leaving $530 \mathrm{~m}$ people without power, primarily in rural communities. Renewables are expected to provide two-thirds of the capacity in mini-grid and off-grid systems in these rural areas where low population density makes grid connection uneconomic [2].

One early market where global demand is showing considerable growth is telecommunications. The requirement for more widespread use of remote base stations is becoming increasingly important with 3G and 4G networks in emerging markets and the added advantage of not requiring the installation of a telephone cable network. China has the world's largest mobile telecommunications network with over 1 million telecommunications base stations, a number which is growing at ten to twenty thousand p.a. [3]. Telecom towers, by their nature, are often positioned in remote locations where reliable grid electricity is not present and network operators have no option but to pursue alternative power sources. Dieselfuelled generators suffer from low efficiency, the high costs of fuel replacement and delivery, the emission of carbon dioxide and other pollutants, and the risk of fuel theft and degradation. Hence there is a growing interest in the use of renewable power sources by telecom stations in order to replace diesel [4] [5]. One recent study estimated that by 2020 there could be 400,000 off-grid telecom base stations operating on renewable power, particularly in remote parts of the developing world, with an associated market size of $\$ 10.5$ billion p.a., [6].

Telecom applications require an extremely reliable 24-hour supply of power, resulting in the need for energy storage for providing backup power during grid outages or primary power during lulls in wind or solar photovoltaic (PV) generation. Historically this has been performed primarily by batteries for backup power (i.e. to cover a defined period of failure in the primary power system) [7] [8] [9] [10], with $\$ 4.7$ to $\$ 7.9$ billion of battery sales per year recorded in China for the telecom industry alone [3]. Lead acid batteries are the main technology used in off-grid systems due to their maturity and low cost. However 'battery-only' solutions have uncertain life expectancies, especially for off-grid applications at sites with large seasonal variations in renewable power production. In such systems batteries encounter long periods at a low state-of-charge (SOC), numerous partial cycles at low SOC and other periods at full charge so preventing the absorption of available renewable electricity. These factors negatively affect battery lifetime [11] [12] [13] [14] and distinguish the telecom application from automotive, portable or uninterrupted power supply applications where deep discharges are experienced but then batteries tend to be quickly recharged and remain near full charge for much of their working lives. Self-discharge mechanisms over time serve to reduce a battery to a partially-charged state, reducing its life expectancy and making it unsuitable for seasonal storage. In a well-designed system with appropriate maintenance batteries can last up to 15 years, but they have been found to fail after only a few years in systems served by solar/wind power. This makes battery lifetime quite short compared to other system components, leading to system unreliability and frequent replacements, making batteries a weak link in remote telecom systems [11] [12] [13] [15]. In general batteries are best operated at high SOC to optimise 
lifetime, as discharging at low SOC degrades batteries more than discharging at high SOC [16]. Some manufacturers have responded by designing deep-cycle batteries specifically for remote power applications, but the potential for extending battery life this way is limited. Whichever battery chemistry is used, there is considerable potential for a solution which can extend battery life by maintaining the SOC within a limited range year-round (e.g. 80-100\%).

Interest in the use of hydrogen, as an alternative to batteries and diesel-fuelled generators, is growing for telecom power [4] [5] [9] [10]. Existing commercial solutions ('hydrogen-only' systems) require bottled hydrogen to be delivered to site [17] [18] [19]. This hydrogen tends to be characterised by a high carbon footprint because it is usually produced centrally via steam methane reformation, then compressed and transported by diesel truck. Alternatively hydrogen-only systems may be powered by on-site renewables, but these are inhibited by the poor round trip efficiency of an electrolyser/fuel-cell combination, which forces the specification of high capacities for the power source, electrolyser and hydrogen store. Therefore hybrid off-grid systems, and the complex sizing, storage and control challenges they present, are receiving considerable research attention [20] [21] [22].

100

101

102

103

104

105

106

107

108

109

110

111

112

113

114

115

Previous investigators have noted that, in systems incorporating hydrogen storage, hydrogen is ideal for seasonal bulk energy storage while batteries are best suited for short-term storage [23]. PV-powered systems incorporating fuel cells and batteries have been found to achieve lower costs and lower PV requirements than battery-only and hydrogen-only systems based on delivered hydrogen [21]. Telecom applications usually need 3-5 days of backup to navigate periods of cloudy weather, and fuel cells are able to offer longer runtimes than batteries (because hydrogen storage tanks are scalable) as well as environmental benefits due to a reduced reliance on lead-acid systems [3]. Hybrid systems have been found to be cheaper than battery-only systems due to lower O\&M costs, and with greater efficiency and reliability than hydrogen-only systems [24]. Previous studies of hybrid hydrogen-battery storage systems have shown that heavy battery use can lead to more efficient systems with reduced PV/wind requirements, but with deep discharges and/or long periods at low SOC which adversely affect battery life [17] [19] [25]. Others have shown that batteries can be protected through reduced usage by placing a heavy reliance on hydrogen, but with adverse impacts on system efficiency and renewable power capacity [20] [26] [27]. Here we show that a compromise can be reached, with batteries improving system efficiency and reducing PV/wind capacity requirements through regular daily cycling, while the hydrogen component serves to maintain battery SOC within narrow limits and so extend battery life.

We propose a hybrid system for off-grid telecom power comprising on-site hydrogen generation by electrolysis, gaseous hydrogen storage and power generation by a PEM fuel cell. The hydrogen technologies are integrated with batteries and a renewable power source(s) to form a 'hydrogen-battery' system. This hybrid configuration, which may be compared with a conventional 'battery-only' system, provides an off-grid solution based entirely on renewable energy. Wind and/or solar energy can be either stored in the battery, or used by the electrolyser to produce hydrogen for storage and later use by the fuel cell. The fuel cell and battery work together to ensure year-round uninterrupted power for the telecom application, while the electrolyser and battery function to capture the electricity generated by the on-site renewable power source(s). The envisaged operating logic is for the hydrogen technologies to support the battery technology, with the hydrogen store providing a seasonal buffer. The foremost design challenge is to identify the capacities and operating regimes of the power source(s), battery, electrolyser and fuel cell for site locations with characteristically different solar and wind regimes. Although an economic analysis was beyond the scope of this investigation, it was assumed that reducing the capacities of the hydrogen technologies (electrolyser, hydrogen storage facility, hydrogen compressor and fuel cell) should make the capital cost of the proposed system more acceptable. Furthermore, the proposed 
approach can provide a greener solution than existing off-grid telecom systems employing fuel cells, because these require compressed hydrogen to be shipped in at regular intervals by diesel truck. Accordingly, new markets can be achieved for small PEM electrolysers in the telecom sector.

\section{Hybrid System Design}

The basic system architecture enables the deployment of both PV and wind power sources at the telecom site (Figure 1). The design consists of an AC bus and a DC bus joined by a bi-directional converter. Power from the wind turbine is fed to the $D C$ bus through a wild rectifier needed to smooth unsteady turbine output. The PV panel voltage varies as it tracks the maximum power point, requiring conversion to reach the bus voltage, and power is fed through an inverter to the AC bus. Separate AC and DC buses enable maximum power point tracking for both the wind turbine and the PV array. The DC telecom load is connected to the DC bus to reduce conversion losses, and it receives power from the battery, the fuel cell, the wind turbine and/or the PV panel. The renewable power output is absorbed by the load, battery and electrolyser with excess renewables stored firstly in the battery to raise SOC, and secondly as hydrogen once the battery is full. Small ancillary AC loads (data logging, ventilation, communication etc.) are connected to the AC bus. This system configuration was analysed for sites where the deployment of one or both types of renewable power source was feasible (Section 4).

Figure 1: Hybrid system layout

\subsection{Telecom Load and Fuel Cell Capacity}


The total power requirement was assumed to be a continuous total load of $1 \mathrm{~kW}$, including the ancillary AC loads and conversion losses from the DC bus. This is a typical size for remote telecom systems [5]. The constancy of the load enabled a simple sizing decision to be made for the fuel cell, which was fixed at $1.0 \mathrm{~kW}$, so that it could meet the total power requirement in the event of a failure of the battery or wind/solar power sources (so improving system reliability). It was assumed that the fuel cell would only be operated at full load; its conversion efficiency (including DC-DC conversion) was taken as $50 \%$ (LHV) at rated power, a value readily achievable with commercial systems [28]. One advantage of a telecom system compared with other off-grid systems is that it doesn't require the fuel cell to be sized to meet a peak load that occurs only briefly and intermittently.

182

\subsection{PV Panels}

Given the low capacity factor of solar energy and the energy conversion losses within the hybrid system, the solar photovoltaic power source (PV) needs to be of much greater capacity than the load. The required PV capacities for various site locations were estimated using the system model. The method used for estimating the electricity yield has been reported previously [29]. Irradiance levels for the locations analysed were estimated using the HOMER modelling package [30]. This synthesises hourly irradiance data onto a horizontal plate from the 22-year (1983-2005) NASA Surface meteorological and Solar Energy (SSE) dataset [31]. Irradiance levels were adjusted to account for shading, ground reflectance, ageing and cable loss effects. The PV panels were implemented at the latitude tilt angle and orientated to face due south to improve yield. The PV power output was assumed to be net of inverter losses.

\subsection{Wind Turbine}

Wind turbine power output was also estimated using HOMER. The turbine power curve was based on a Proven $6 \mathrm{~kW}$ turbine (with a $15 \mathrm{~m}$ hub height and a 90\% efficient rectifier [32]), and it was scaled linearly with capacity where the model recommended small deviations from the $6 \mathrm{~kW}$ value. Monthly windspeeds were linearly interpolated from the University of East Anglia's Climate Research Unit CL v2.0 dataset, derived from 1961-1990 monthly means and reported at 10-minute resolution and 10m above ground level [33]. Hourly wind-speed values were synthesized from this dataset in HOMER using typical values of $0.01 \mathrm{~m}$ surface roughness length, 0.85 autocorrelation factor, 0.25 diurnal pattern strength, 14:00 time of peak wind speed and a Weibull factor that scales linearly with average wind speed. One such turbine is normally sufficient for telecom systems.

\subsection{Electrolyser and Hydrogen Storage}

The electrolyser model was based on a novel proton-exchange membrane (PEM) electrolyser designed for generating hydrogen from a renewable power source off-grid [29]. The electrolyser self-pressurises to 15 bar and incorporates a passive operating mechanism for achieving a very low balance-of-plant power consumption. It is more efficient at part-load than full load (Figure 2), enabling hydrogen to be produced with high efficiency at low input power levels. The electrolyser capacity was fixed at $1.6 \mathrm{~kW}$ at which it achieved a stack efficiency of $75 \%$ (HHV); the minimum operating point was taken as $10 \%$ of full capacity (i.e. $0.16 \mathrm{~kW}$ ), at which it achieved a stack efficiency of $93 \%$ (HHV), with power levels below this sent to the battery.

It was assumed that the product hydrogen from the electrolyser would be accumulated in a 15 bar buffer store then compressed for storage in conventional 200 bar steel cylinders. This requirement for gas compression is driven by the space available at the telecom site. Given the hydrogen generation pressure of 15 bar, it was considered that any capacity requirement of $>10 \mathrm{~kg} \mathrm{H} 2$ would make the use of a gas compressor essential, in order to limit the system footprint. Additionally a minimum storage level of $1 \mathrm{~kg}$ was specified, which allows approximately 17 hours of fuel cell operation in the event of an emergency. 
A value for the compression work $w_{c}$ from 15 bar of $4.35 \mathrm{kWh} / \mathrm{kg}$ was used, calculated from the relation below derived from the ideal gas equation for isothermal compression at $293 \mathrm{~K}$ with an ideal gas constant $\mathrm{R}$ of $8.31 \mathrm{~kJ} \mathrm{kmol}^{-1} \mathrm{~K}^{-1}$, relative molecular mass of hydrogen $\mathrm{RMM}_{\mathrm{H} 2}$ of $2.016 \mathrm{~kg} \mathrm{kmol}^{-1}$ and a compression efficiency $\eta_{c}$ of $20 \%$. Inaccuracies in the compression work value resulting from deviations from the ideal gas equation are thought to be small compared with the uncertainties in the value of compression efficiency, which can vary considerably with the compression technology used. The compressor work is subtracted from the electricity otherwise employed for electrolysis as shown in Appendix A. This results in an electrolyser system efficiency of about 70\% (HHV) at a power input of $1.6 \mathrm{~kW}$, which increases at part-load (Figure 2).

$$
w_{c}=\frac{R T}{3600 \eta_{c} R M M_{H_{2}}} \ln \frac{p_{2}}{p_{1}}
$$
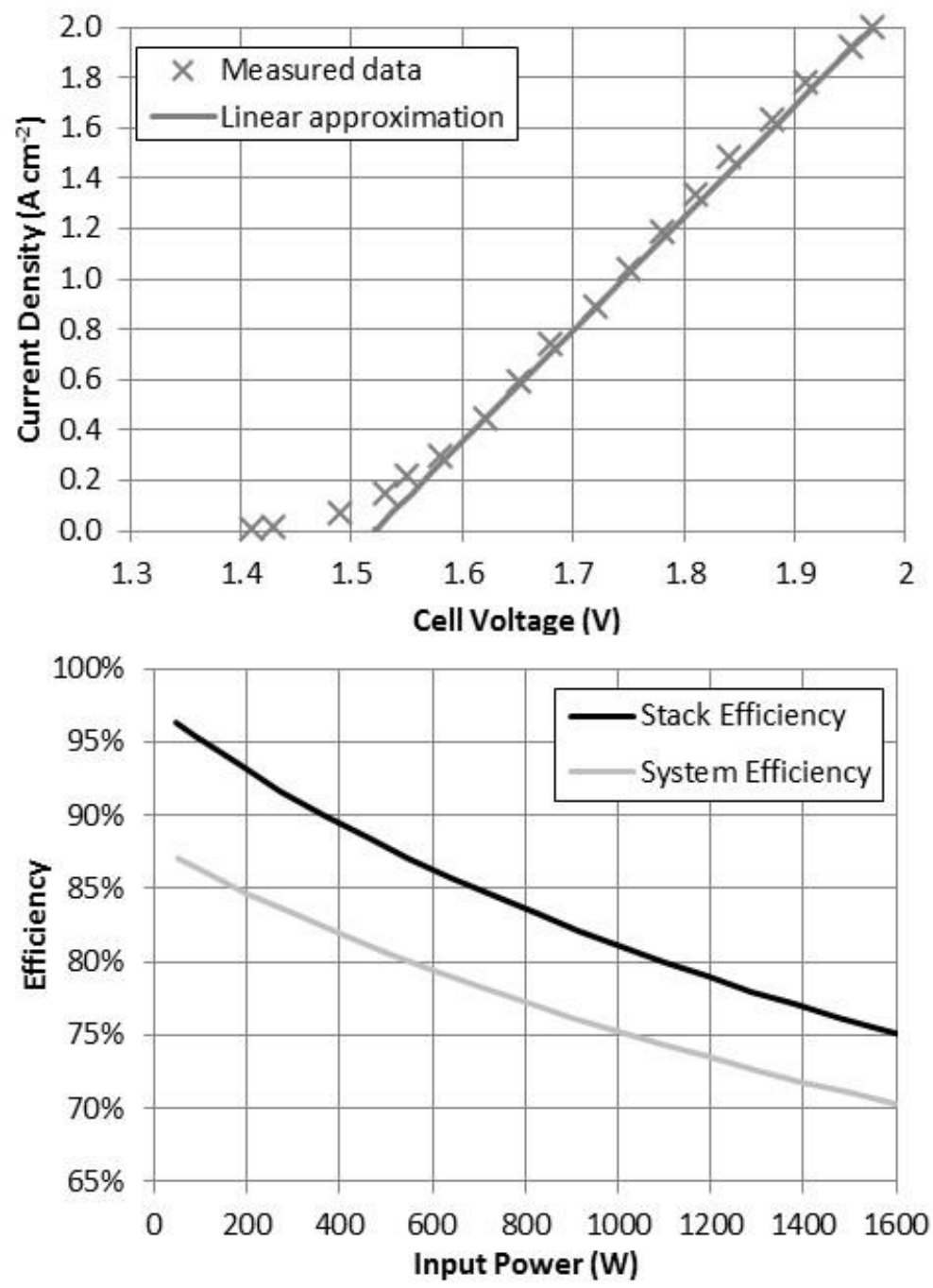

232 Figure 2: Electrolyser performance 
Because of their higher round trip efficiency, the batteries were sized to meet the majority of the electrical work done. The battery model was based on Rolls 4KS25P deep-discharge batteries which are available in capacities of up to $7.6 \mathrm{kWh}$ at low discharge rates [34]. The round-trip efficiency was taken as $80 \%$, with a $2 \%$ per month self-discharge rate typical for lead-acid batteries. The battery SOC value was computed by dividing the energy stored (and available for discharge when required) by the maximum discharge capacity of the battery. The model assumed simple constant current charging of the battery.

\section{Model}

A model evaluated at hourly intervals was developed to explore the effect of different size components on the performance of the hybrid system. The design objectives were as follows.

- Manage the temporal variations in the renewable power supply and in the charge levels of the battery and hydrogen stores, to ensure the telecom load can be met year-round, and so define a design solution for the hybrid system.

- Maintain the battery close to a high SOC 'ceiling level' and avoid leaving it for long periods at a low SOC 'floor level', in order to prolong battery life.

- Minimise the required PV/wind capacity, hydrogen storage capacity and battery capacity to reduce system costs and footprint.

- Enable renewable power generation in excess of the electrolyser capacity to charge the battery. This allows a smaller electrolyser capacity to be used.

- Minimise curtailment of the renewable power source without oversizing other system components, which are then under-utilised for the rest of the year.

- Maintain a hydrogen store charge level sufficient to (i) guarantee year-round operation, (ii) provide emergency telecom availability in the event of a systems failure and (iii) allow maintenance without necessarily interrupting operation of the telecom system.

To achieve this, the electrolyser absorbs up to $1.6 \mathrm{~kW}$ of renewables supply in excess of the telecom load, provided that there is sufficient room in the hydrogen store to accommodate the gas produced and the battery is at its SOC ceiling. This ceiling was chosen to be typically $95-98 \%$ of full charge; high enough to prioritise maintaining the battery at the highest SOCs possible, whilst leaving some headroom for the battery to absorb subsequent additional renewables input if available (on the next sunny day, for example). The battery absorbs any renewables supply in excess of the combined electrolyser and telecom load. If the battery is fully charged and the electrolyser is operating at full capacity, any additional renewable supply is curtailed; the model aims to minimise the amount of curtailed renewables, though some wastage is inevitable.

The battery discharges the amount required to meet the telecom load if there is insufficient renewables supply. If the battery SOC drops below a chosen SOC floor value, the fuel cell is subsequently switched on to prevent deep discharging of the battery. Any incoming renewable power then powers the telecoms load directly, with the fuel cell picking up any shortfall. As the fuel cell output is fixed at $1 \mathrm{~kW}$, any excess fuel cell generation above that used to power the telecoms load then recharges the battery; if incoming renewables in fact exceeds $1 \mathrm{~kW}$, the model records this as $1 \mathrm{~kW}$ of renewables powering the telecom load and $1 \mathrm{~kW}$ of fuel cell output (and any additional renewables) recharging the battery, in order to elevate the SOC as quickly as possible. Incorporating a weather forecasting capability could allow an operator to decide to operate the fuel cell on the basis of upcoming renewables production, but this was beyond the scope of the current investigation. Once the battery SOC exceeds the SOC floor value, the fuel cell is switched off to conserve hydrogen. The model did not impose a minimum runtime on the fuel 
cell, so sometimes it switched off after only one hour. The fuel cell never operated if the electrolyser was running or the battery was discharging. The SOC floor value was chosen to be typically $80 \%$; high enough to protect the battery from deep discharge, but low enough to prevent emptying the hydrogen store prematurely.

There is considerable scope to adjust the SOC floor value (to start the fuel cell) and the ceiling value (to start the electrolyser). Raising these values increases the battery SOC level but can empty the hydrogen store prematurely, requiring an increased renewable power capacity to make up the short-fall. The model permitted the use of separate winter and summer floor/ceiling values to respect the variation in renewable supply, but it was found that similar summer and winter values were able to maintain high SOC levels year-round. Ultimately a system could incorporate updated weather forecasts to predict when renewables availability will be low and fuel cell operation is required to prevent SOC dropping too low, or when the electrolyser should be operated to create battery headroom to fully absorb renewables on an upcoming windy or sunny day.

The model demonstrated that component sizing was determined by a number of competing factors. For example, PV and wind turbine capacities were kept low to reduce costs, but high enough to ensure that final tank and battery levels matched their initial values. Battery SOC was kept high year-round, and the amount of shed renewables was kept low. The hydrogen storage capacity was kept low to reduce costs, but it had to be large enough to capture as much renewable supply as possible during plentiful periods to help maintain battery SOC during leaner times of the year. The number of batteries was also kept low to reduce costs, but high enough to avoid deep discharges with the aid of the hydrogen storage system. The component sizes reported here satisfy these design constraints; a cost model would allow these to be optimized further.

To demonstrate the benefits of the hybrid hydrogen-battery system, it was compared with an otherwise equivalent battery-only system. Adding hydrogen storage will improve the reliability of any existing system simply by virtue of adding more energy storage capacity, so for a valid comparison the number of batteries in the battery-only system was increased by an amount equivalent to the energy stored as hydrogen in the hybrid system. For example, $5 \mathrm{~kg}$ of hydrogen generates $83 \mathrm{kWh}$ through a $50 \%$ efficient fuel cell, which is equivalent to about eleven $7.6 \mathrm{kWh}_{\mathrm{e}}$ batteries. The PV/wind capacity was also kept the same for the battery-only system to allow like-for-like comparisons, although it is acknowledged that a system designer could choose to install slightly smaller power sources to reduce capital expenditure and incur worse minimum and average SOC values than reported here.

\subsection{Location Selection}

Three sites for analysis were chosen because of their significant but distinct renewables resource profiles (Phoenix, Arizona; Heraklion, Crete; and Reykjavik, Iceland). Phoenix was selected for its high solar resource, while Reykjavik was chosen for its high wind-speeds. Both have significant seasonal swings in their renewable supply, with PV output peaking in Phoenix in the summer and wind generation peaking in Reykjavik in the winter (Figure 3). Heraklion, which is of similar latitude to Phoenix, was selected because it has both a significant solar and wind resource. Heraklion has a peak in solar availability in the summer and a peak in wind supply in the winter, with additional significant summer breezes in July and August (Figure 3).

The total PV resource for Phoenix was estimated at 1,813 kWh p.a. / $\mathrm{kW}_{\mathrm{p}}$ (Table 1), which is high for PV systems. The total wind resource for Reykjavik was $2,563 \mathrm{kWh}$ p.a. / $\mathrm{kW}_{\mathrm{p}}$, which is high for small, onshore 
installations. The PV resource for Heraklion was $1,511 \mathrm{kWh}$ p.a. / $\mathrm{kW}_{\mathrm{p}}$, while the wind resource was 1,303 $\mathrm{kWh}$ p.a. / $\mathrm{kW}_{\mathrm{p}}$ (which is much lower than for Reykjavik but still significant).

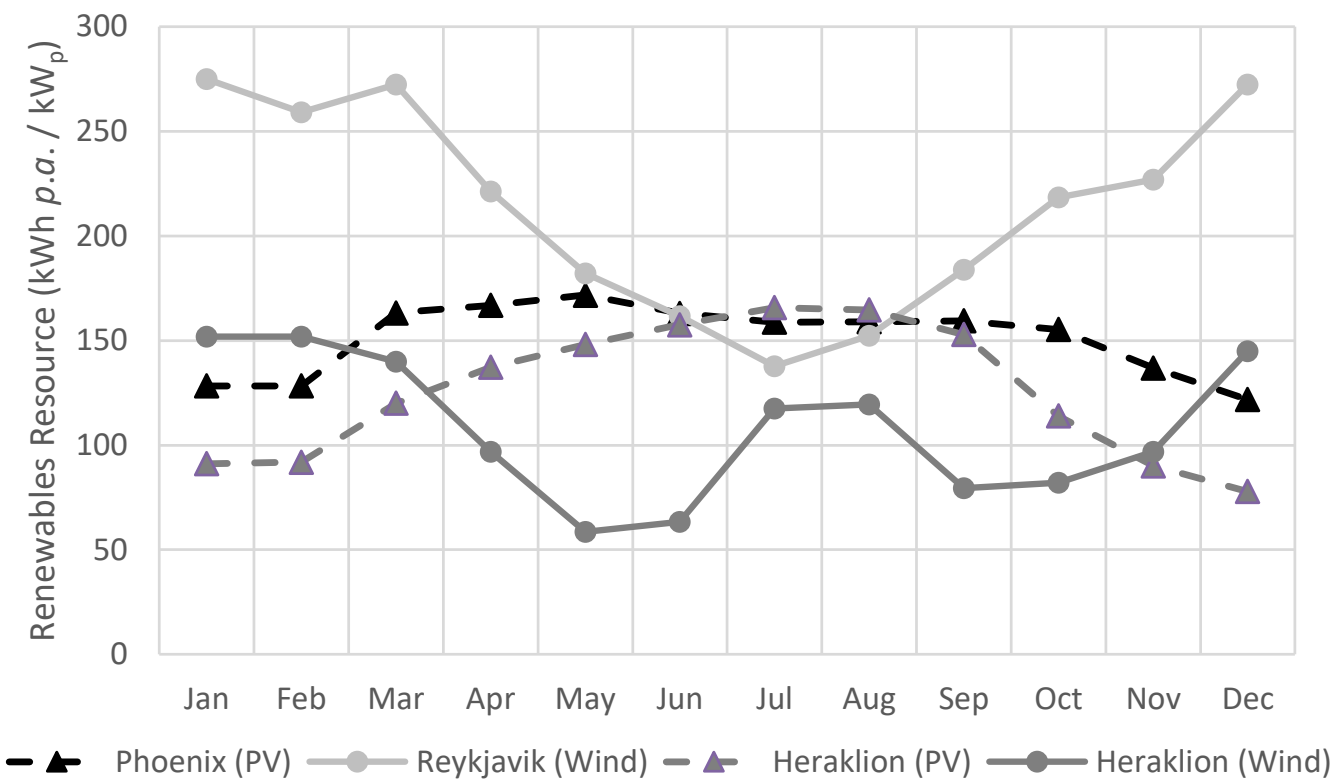

332 Figure 3: Seasonal variation in renewables resource

\section{Results and Discussion}

The required component sizes found for the three sites are shown in Table 1. Results are shown firstly for the baseline battery-only system, and secondly for a hybrid hydrogen-battery system with the same capacity of renewable generation but where some of the battery storage has been replaced with hydrogen storage. The PV-only site (Phoenix) required $6.25 \mathrm{~kW}$ of PV and 65 batteries for its battery-only system, and had an average battery SOC over the course of a year of $90.0 \%$ with a minimum SOC of $54.7 \%$, spending over 4 consecutive months without a full charge (Figure 4). The battery store experienced a total of 1,948 hours p.a. (22.2\% of the year) below $80 \%$ SOC. Replacing 35 of the batteries with an equivalent $17 \mathrm{~kg}$ of hydrogen storage raised the annual average battery SOC to $95.2 \%$ with a much higher minimum SOC of $85.9 \%$. The hydrogen store reached its minimum $1 \mathrm{~kg}$ reserve level in February before filling up over the summer, reaching maximum capacity at the end of October before emptying again over the winter (Figure 4). The battery SOC was a little lower in winter when renewable power generation was scarcer, but remained above $85 \%$ SOC throughout the year with regular full charges. 


\begin{tabular}{|l|c|c|c|c|c|c|}
\cline { 2 - 7 } \multicolumn{1}{c|}{} & \multicolumn{2}{c|}{ Phoenix } & \multicolumn{2}{c|}{ Reykjavik } & \multicolumn{2}{c|}{ Heraklion } \\
\cline { 2 - 7 } \multicolumn{1}{c|}{} & $\begin{array}{c}\text { Battery- } \\
\text { only }\end{array}$ & $\begin{array}{c}\mathrm{H}_{2^{-}} \\
\text {Battery }\end{array}$ & $\begin{array}{c}\text { Battery- } \\
\text { only }\end{array}$ & $\begin{array}{c}\mathrm{H}_{2^{-}} \\
\text {Battery }\end{array}$ & $\begin{array}{c}\text { Battery- } \\
\text { only }\end{array}$ & $\begin{array}{c}\mathrm{H}_{2^{-}} \\
\text {Battery }\end{array}$ \\
\hline PV resource (kWh p.a./ $\mathrm{kW}_{\mathrm{p}}$ ) & 1,813 & 1,813 & - & - & 1,511 & 1,511 \\
\hline Wind resource $(\mathrm{kWh}$ p.a./ kW ) & - & - & 2,563 & 2,563 & 1,303 & 1,303 \\
\hline PV capacity (kW) & 6.25 & 6.25 & - & - & 3 & 3 \\
\hline Wind capacity (kW) & - & - & 4.5 & 4.5 & 4.75 & 4.75 \\
\hline Hydrogen storage capacity (kg) & - & 17 & - & 31 & - & 13 \\
\hline Number of batteries* & 65 & 30 & 86 & 20 & 63 & 25 \\
\hline Battery capacity (kWh) & 497 & 228 & 656 & 152 & 480 & 190 \\
\hline Average battery SOC (\%) & 90.0 & 95.2 & 81.0 & 93.6 & 87.9 & 92.0 \\
\hline Minimum battery SOC (\%) & 54.7 & 85.9 & 36.7 & 85.5 & 54.5 & 81.5 \\
\hline Hours p.a. at < 80\% SOC & 1,948 & 0 & 3,121 & 0 & 2,820 & 0 \\
\hline Electrolyser start-ups per year & - & 226 & - & 298 & - & 208 \\
\hline Average electrolyser runtime (h) & - & 3.6 & - & 6.4 & - & 5.1 \\
\hline Fuel cell start-ups per year & - & 54 & - & 231 & - & 120 \\
\hline Average fuel cell runtime (h) & - & 6.4 & - & 3.2 & & 3.4 \\
\hline
\end{tabular}

* Rolls 4KS25P deep-discharge batteries of $7.6 \mathrm{kWh}$ capacity [34]

Table 1: Component sizes for the hybrid and battery-only systems

The monthly variations in energy production (both PV generation and discharging of the battery and fuel cell), and consumption (by the telecoms load, battery and electrolyser) are shown in Figure 5, with annual totals shown in Table 2. Electrolyser operation occurred mainly in the summer months to fill the hydrogen store with excess PV energy, with 1,149 kWh sent annually to the electrolyser versus $5,865 \mathrm{kWh}$ sent to the battery (i.e. $16.4 \%$ of the total sent to storage). A low average runtime of 3.6 hours per start-up indicates that surplus PV generation occurs only for short periods. Fuel cell operation occurred mainly in winter to cover the valley in PV production, with the majority of the generated electricity $(292 \mathrm{kWh})$ used to power the telecoms load directly and the remainder $(53 \mathrm{kWh})$ to recharge the depleted battery. Using the fuel cell to recharge the battery this way reduces system efficiency slightly, but should increase battery longevity. A long average fuel cell runtime of $6.4 \mathrm{hrs}$ per start-up indicates that the fuel cell often had to run overnight due to the lack of PV generation. Accordingly only $43 \%$ of the telecom power requirement could be met directly by the power source (Figure 6) with the remainder coming from the battery or the fuel cell. Likewise only $33 \%$ of PV generation could be used by the telecoms load directly, with the majority of the remainder stored for use later (Figure 7). This demonstrates the high usage of batteries for daily cycling in PV systems, and hence the need for regular cycling to occur at elevated SOC if a long battery life is to be achieved. The battery round-trip efficiency was slightly below $80 \%$ due to self-discharge. Curtailment of PV production was limited to $531 \mathrm{kWh}$ (4.7\% of total annual production) in the hybrid system, and it occurred primarily in the summer months. This is less than half the 1,191 kWh of curtailment required by the battery-only system ( $10.5 \%$ of its total annual production) which spends most of the summer at $100 \%$ SOC, unable to accept any excess PV. 


\begin{tabular}{|c|c|c|c|c|c|c|c|c|c|c|c|}
\hline & & & \multicolumn{4}{|c|}{ Battery-only Storage System } & \multicolumn{5}{|c|}{ Hydrogen-Battery Hybrid Storage System } \\
\hline & & & \multicolumn{3}{|c|}{ Consumption (kWh p.a.) } & \multirow{2}{*}{$\begin{array}{c}\text { Total } \\
\text { Production } \\
\text { (kWh p.a.) }\end{array}$} & \multicolumn{4}{|c|}{ Consumption (kWh p.a.) } & \multirow{2}{*}{$\begin{array}{c}\text { Total } \\
\text { Production } \\
\text { (kWh p.a.) }\end{array}$} \\
\hline & & & $\begin{array}{c}\text { Telecoms } \\
\text { Load }\end{array}$ & $\begin{array}{c}\text { Battery } \\
\text { In }\end{array}$ & $\begin{array}{c}\text { Shed } \\
\text { Renewables }\end{array}$ & & $\begin{array}{c}\text { Telecoms } \\
\text { Load }\end{array}$ & $\begin{array}{c}\text { Battery } \\
\text { In }\end{array}$ & Electrolyser & $\begin{array}{c}\text { Shed } \\
\text { Renewables }\end{array}$ & \\
\hline \multirow{4}{*}{ Phoenix } & \multirow{3}{*}{$\begin{array}{l}\text { Production } \\
(\mathrm{kWh} \text { p.a. })\end{array}$} & PV Generation & 3,785 & 6,354 & 1,191 & 11,330 & 3,785 & 5,865 & 1,149 & 531 & 11,330 \\
\hline & & Battery Out & 4,975 & - & - & 4,975 & 4,683 & - & - & - & 4,683 \\
\hline & & Fuel Cell & - & - & - & - & 292 & 53 & - & - & 345 \\
\hline & \multicolumn{2}{|c|}{ Total Consumption (kWh p.a.) } & 8,760 & 6,354 & 1,191 & 16,305 & 8,760 & 5,918 & 1,149 & 531 & 16,358 \\
\hline \multirow{4}{*}{ Reykjavik } & \multirow{3}{*}{$\begin{array}{l}\text { Production } \\
(\mathrm{kWh} \text { p.a.) }\end{array}$} & Wind Generation & 6,026 & 3,579 & 1,928 & 11,533 & 6,026 & 2,588 & 2,439 & 480 & 11,533 \\
\hline & & Battery Out & 2,734 & - & - & 2,734 & 2,208 & - & - & - & 2,208 \\
\hline & & Fuel Cell & - & - & - & - & 526 & 215 & - & - & 741 \\
\hline & \multicolumn{2}{|c|}{ Total Consumption (kWh p.a.) } & 8,760 & 3,579 & 1,928 & 14,267 & 8,760 & 2,803 & 2,439 & 480 & 14,482 \\
\hline \multirow{5}{*}{ Heraklion } & \multirow{4}{*}{$\begin{array}{l}\text { Production } \\
\text { (kWh p.a.) }\end{array}$} & PV Generation & 2,153 & 2,044 & 337 & 4,534 & 2,153 & 1,848 & 472 & 61 & 4,534 \\
\hline & & Wind Generation & 3,225 & 2,287 & 676 & 6,188 & 3,225 & 1,955 & 857 & 151 & 6,188 \\
\hline & & Battery Out & 3,382 & - & - & 3,382 & 3,093 & - & - & - & 3,093 \\
\hline & & Fuel Cell & - & - & - & - & 289 & 116 & - & - & 405 \\
\hline & \multicolumn{2}{|c|}{ Total Consumption (kWh p.a.) } & 8,760 & 4,332 & 1,013 & 14,104 & 8,760 & 3,919 & 1,329 & 212 & 14,220 \\
\hline
\end{tabular}

372 Table 2: Energy flows for battery-only and hybrid systems

373

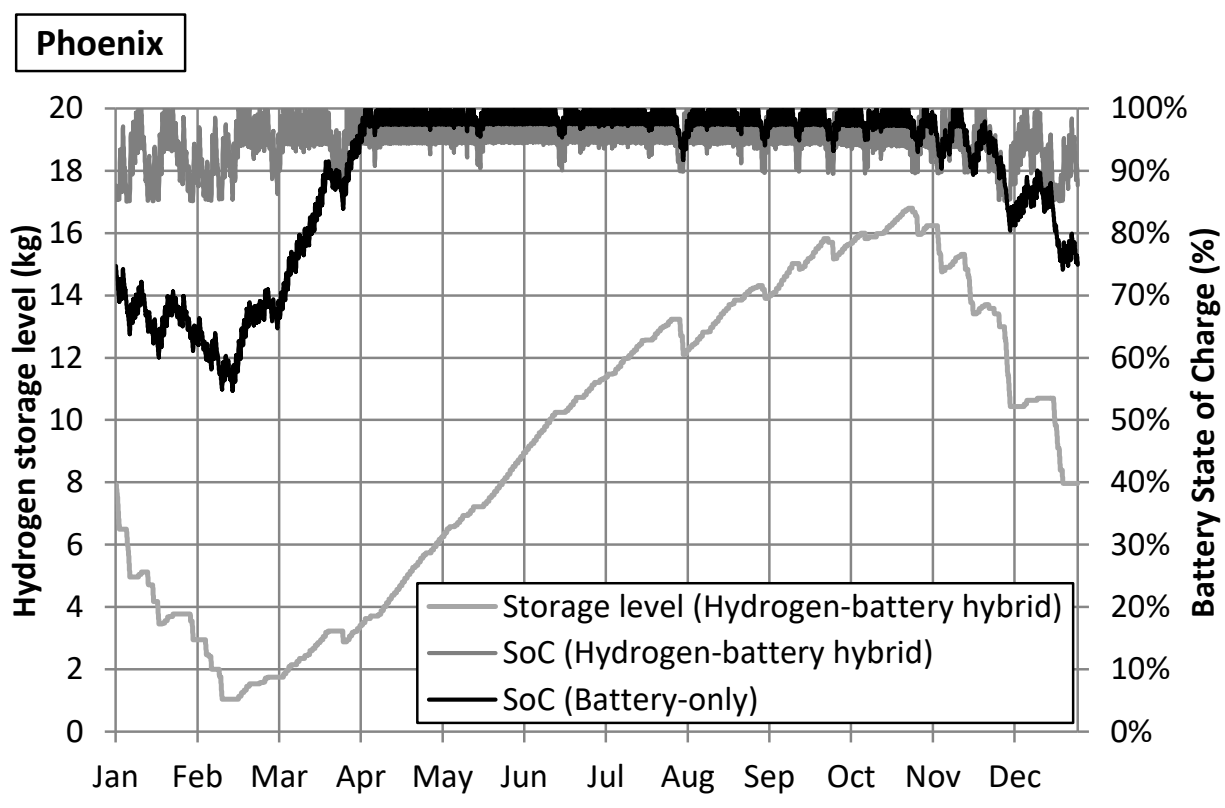

374

Figure 4: Hydrogen storage level and battery SOC variations (Phoenix) 

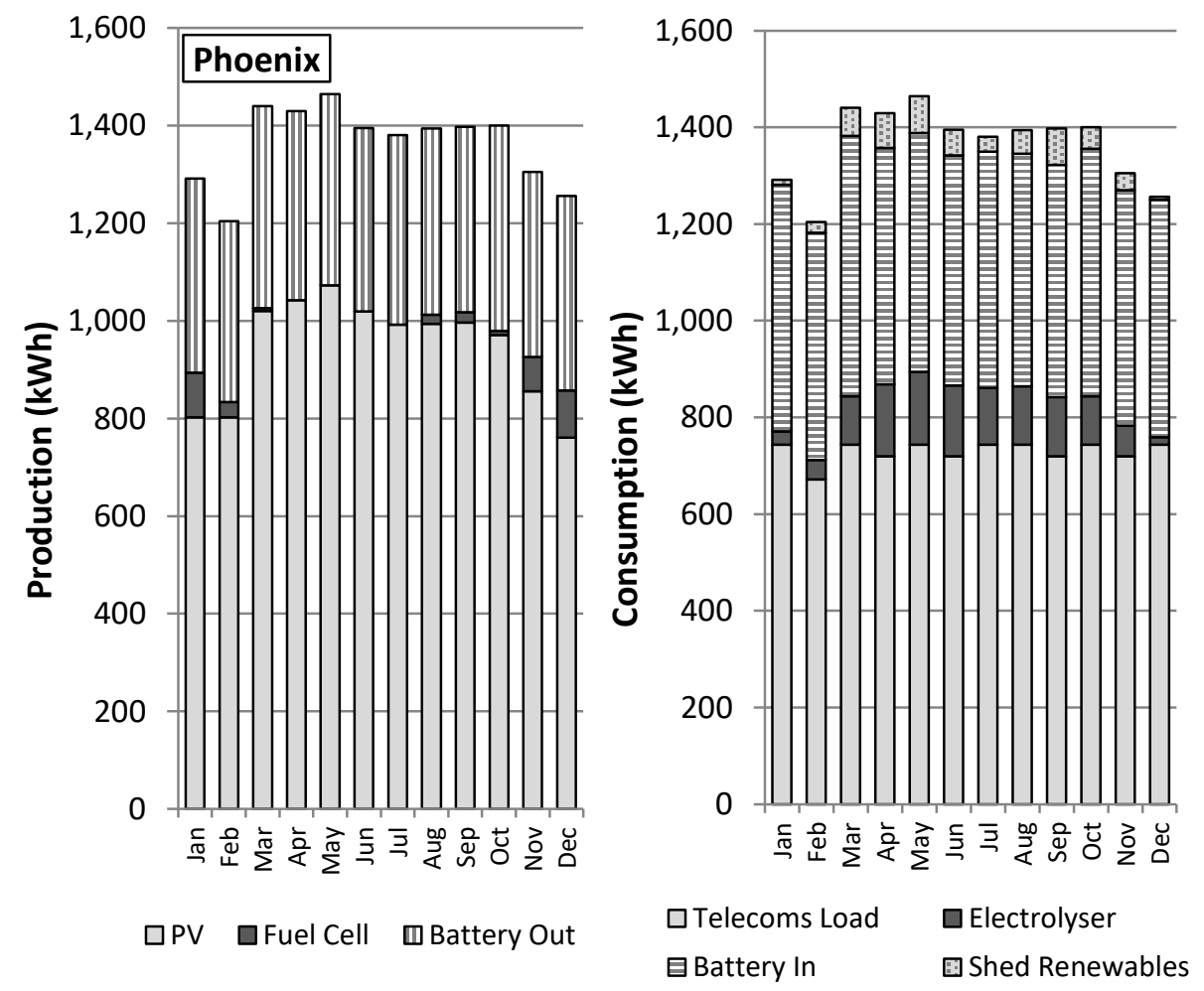

378 Figure 5: Monthly variations in electricity production and consumption (Phoenix)
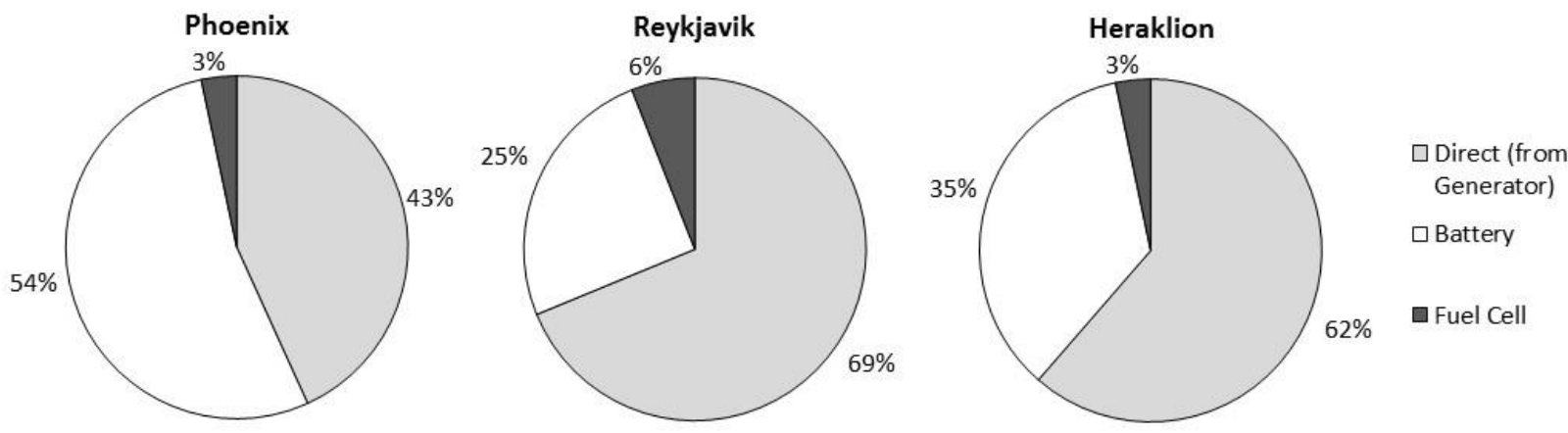

Figure 6: Source of telecoms power in hybrid hydrogen-battery system (8,760 kWh p.a. total) 

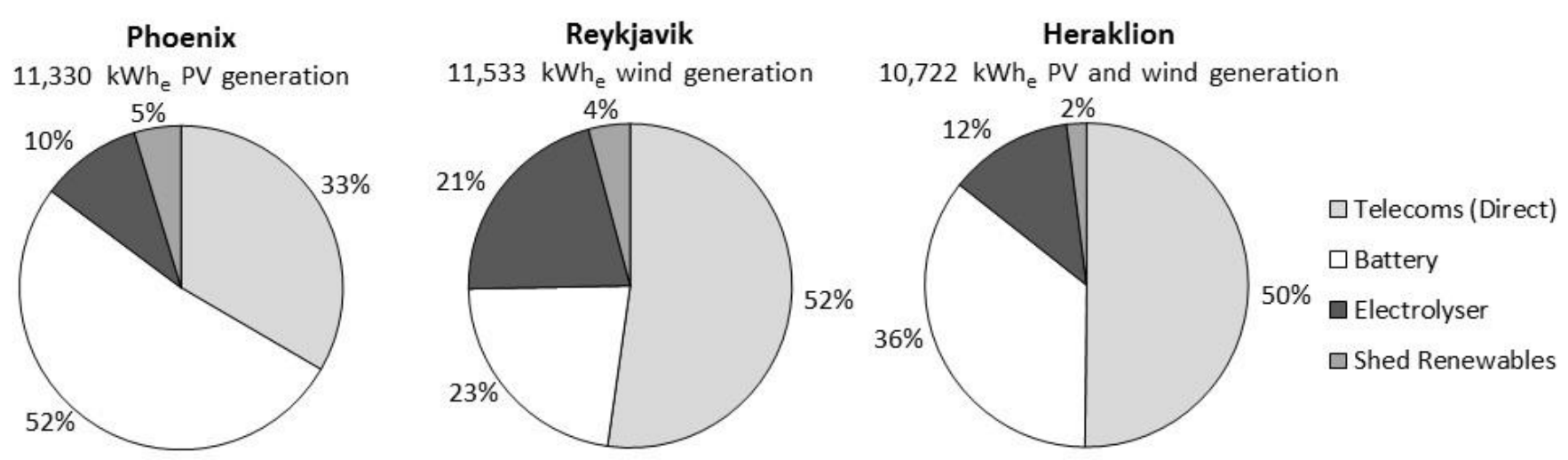

Figure 7: Consumption of renewable power by hybrid hydrogen-battery system

The wind-only site (Reykjavik) required a $4.5 \mathrm{~kW}$ turbine capacity and 86 batteries for its battery-only system, and had an average battery SOC over the course of a year of $81.0 \%$ with a very low minimum SOC of $36.7 \%$ (Table 1). It spent nearly 6 consecutive months without a full charge (Figure 8 ), and a total of $3,121 \mathrm{hrs}$ p.a. (35.6\% of the year) below $80 \%$ SOC; remaining around $40 \%$ SOC for most of August and September. By contrast, the equivalent hybrid hydrogen-battery system required a substantial $31 \mathrm{~kg}$ of hydrogen storage (reflecting the considerable seasonal storage requirements at Reykjavik), but only 20 batteries (less than a quarter of the battery-only system). The hybrid system achieved an average battery SOC of $93.6 \%$ with a minimum SOC of $85.5 \%$ with regular full charges throughout the year, indicating the huge benefit that the hydrogen component of the hybrid system can offer. Peak wind production occurs in winter, so the hydrogen storage level reaches a maximum at the end of April before emptying over the summer then reaching its minimum level in October before filling again over the winter (Figure 8), i.e. the inverse behaviour of the PV powered system in Phoenix. The battery SOC was a little lower in summer when wind availability was reduced, but remained above $85 \%$ SOC throughout. The relatively low capacity power source $(4.5 \mathrm{~kW})$ compared with Phoenix reflects the high capacity factor for wind power in Reykjavik versus solar power in Phoenix.

Electrolyser operation occurred mainly in winter to fill the store with excess wind energy (Figure 9), with $2,439 \mathrm{kWh}$ overall sent to the electrolyser versus $2,588 \mathrm{kWh}$ sent to the battery (i.e. $48.5 \%$ of the total sent to storage, Table 2). This increased use of the electrolyser, resulting from the more pronounced seasonal variation in wind generation than the seasonal variation in PV generation for Phoenix, combined with a reduction in battery usage as wind generation continued overnight, demonstrates the prominent role that the hydrogen component must play in Reykjavik, with the electrolyser actually capturing more surplus wind than the battery during the winter months. A higher average electrolyser runtime of 6.4 hours per start-up indicates that excess wind tends to occur for longer periods than for PV systems. Fuel cell operation occurred mainly during the summer to overcome the shortfall in wind production, with the majority $(526 \mathrm{kWh})$ used to power the telecoms load directly and the remainder ( $215 \mathrm{kWh}$ ) to recharge the depleted battery. A lower average fuel cell runtime of 3.2 hours per start-up occurred as generation from wind is more continuous than from PV, allowing battery SOC to be returned above its lower limit more quickly. The continued generation from wind overnight also meant that $69 \%$ of the telecom power requirement could be met directly by the power source (Figure 6), with $52 \%$ of wind generation being used by the telecoms load directly (Figure 7). This reduced battery operation suggests that batteries should last longer in wind-based hybrid systems relative to PV-based applications. The amount of curtailed renewables was limited to $480 \mathrm{kWh}$ (4.2\% of total wind production) and occurred primarily in 
the winter. This is about one quarter of the $1,928 \mathrm{kWh}$ of curtailment required in the equivalent batteryonly system ( $16.7 \%$ of total production) where the battery remains at $100 \%$ SOC for most of the winter months, unable to accept any excess wind.

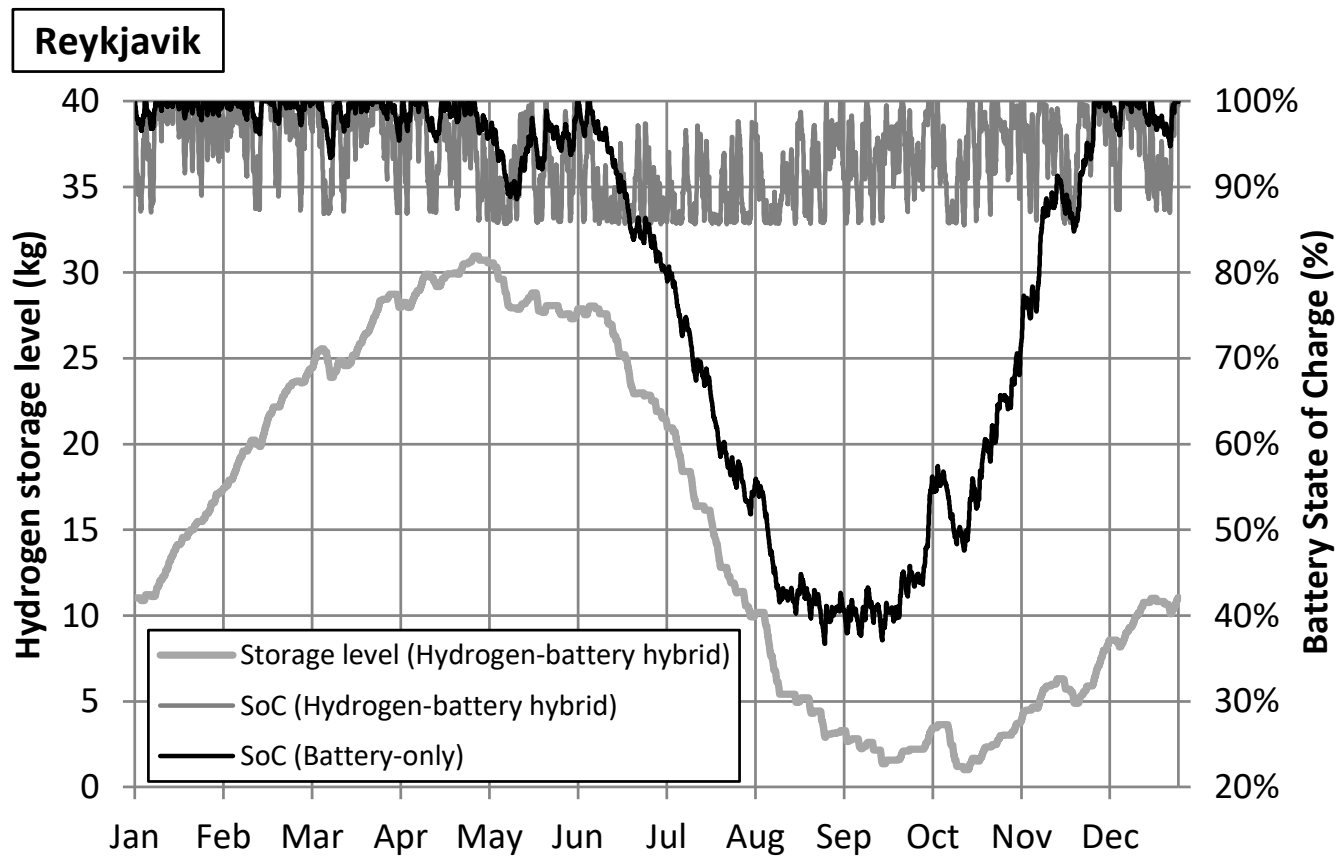

Figure 8: Hydrogen storage level and battery SOC variations (Reykjavik)
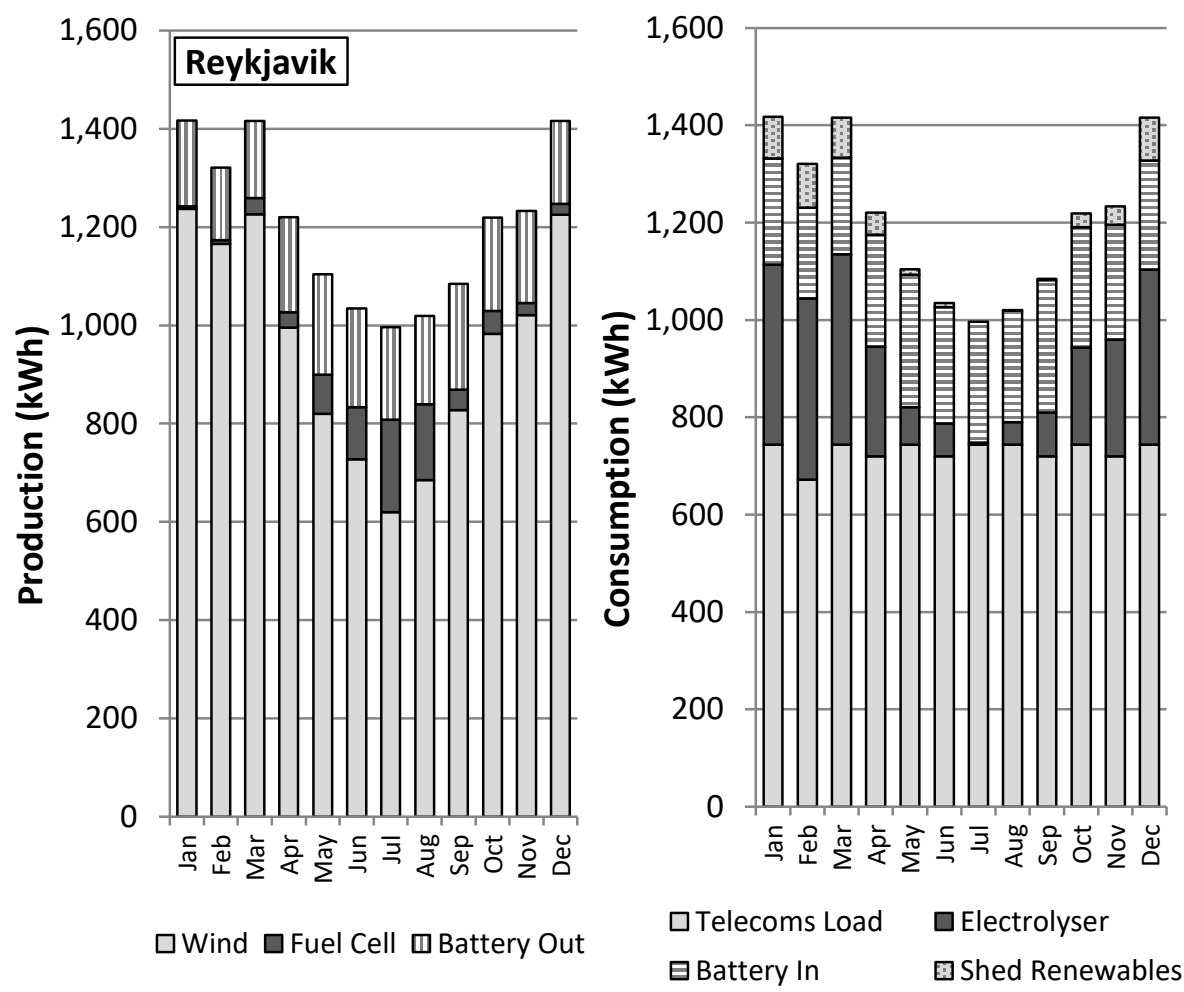
The site with good solar and wind resources (Heraklion) required a similar size wind turbine to Reykjavik $(4.75 \mathrm{~kW})$ and a relatively small PV array ( $3 \mathrm{~kW})$ compared with Phoenix (Table 1). This dual generation system had the least electricity generation requirement when compared with the other two sites (Table 2). The hybrid storage system needed a broadly similar number of batteries to Reykjavik but a much reduced hydrogen storage requirement of only $13 \mathrm{~kg}$. Having two distinct power sources led to two peaks in hydrogen store level per year (Figure 10); one occurring at the end of April due to high wind power production over the winter, and another at the end of September due to high PV yield in the summer. The system achieved an average battery SOC of $92.0 \%$ with a minimum SOC of $81.5 \%$ and regular full charges, while the equivalent battery-only system required 63 batteries and achieved an average SOC of $87.9 \%$ and a much lower minimum SOC of $54.5 \%$. This battery-only system would spend nearly 4 months without a full charge, and 2,820 hrs p.a. (32.2\% of the year) below $80 \%$ SOC.

Electrolyser operation occurred in the summer and winter months to capture the excess PV and wind respectively, and the average runtime of 5.1 hours per start-up is about midway between the values obtained for Phoenix and Reykjavik. Fuel cell operation occurred mainly in the spring and autumn to fill the valleys in the renewable generation profile (Figure 11). The low average fuel cell runtime of 3.4 hours per start-up was nearly the same as for Reykjavik, reflecting shorter periods of low renewables generation than for a system powered by PV alone. Battery throughput was higher than for the wind-only site (Reykjavik) with more overnight discharging, but lower than for the PV-only site (Phoenix). 62\% of the telecom power requirement could be met directly by the renewable power sources (Figure 6), with $50 \%$ of renewable generation being used by the telecoms load directly (Figure 7); both figures are between the values for Phoenix and Reykjavik, but closer to the values for Reykjavik. The required curtailment level was very low, only $213 \mathrm{kWh}$ ( $2.0 \%$ of total generation), which amounts to about one-fifth of the 1,013 $\mathrm{kWh}$ that must be shed by the equivalent battery-only system for this site. Hence a hybrid system that can access two types of renewable energy resource is very effective at utilising the generated electricity.

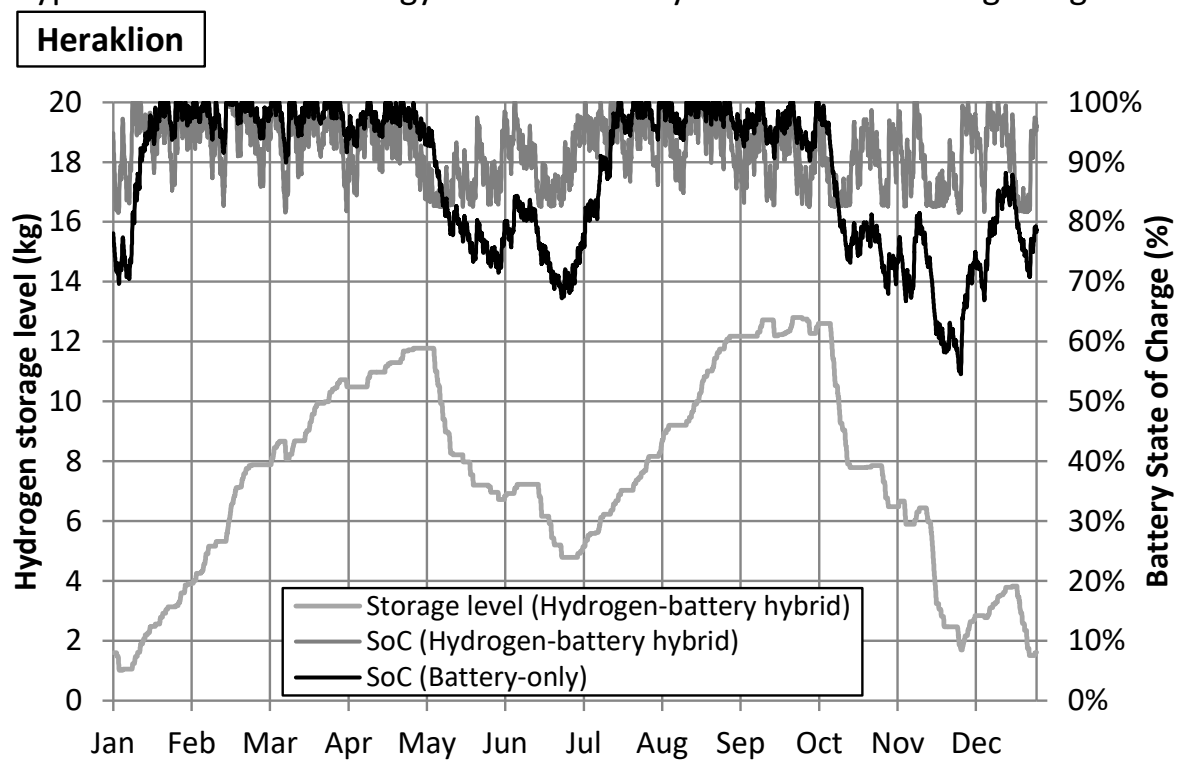

Figure 10: Hydrogen storage level and battery SOC variations (Heraklion) 

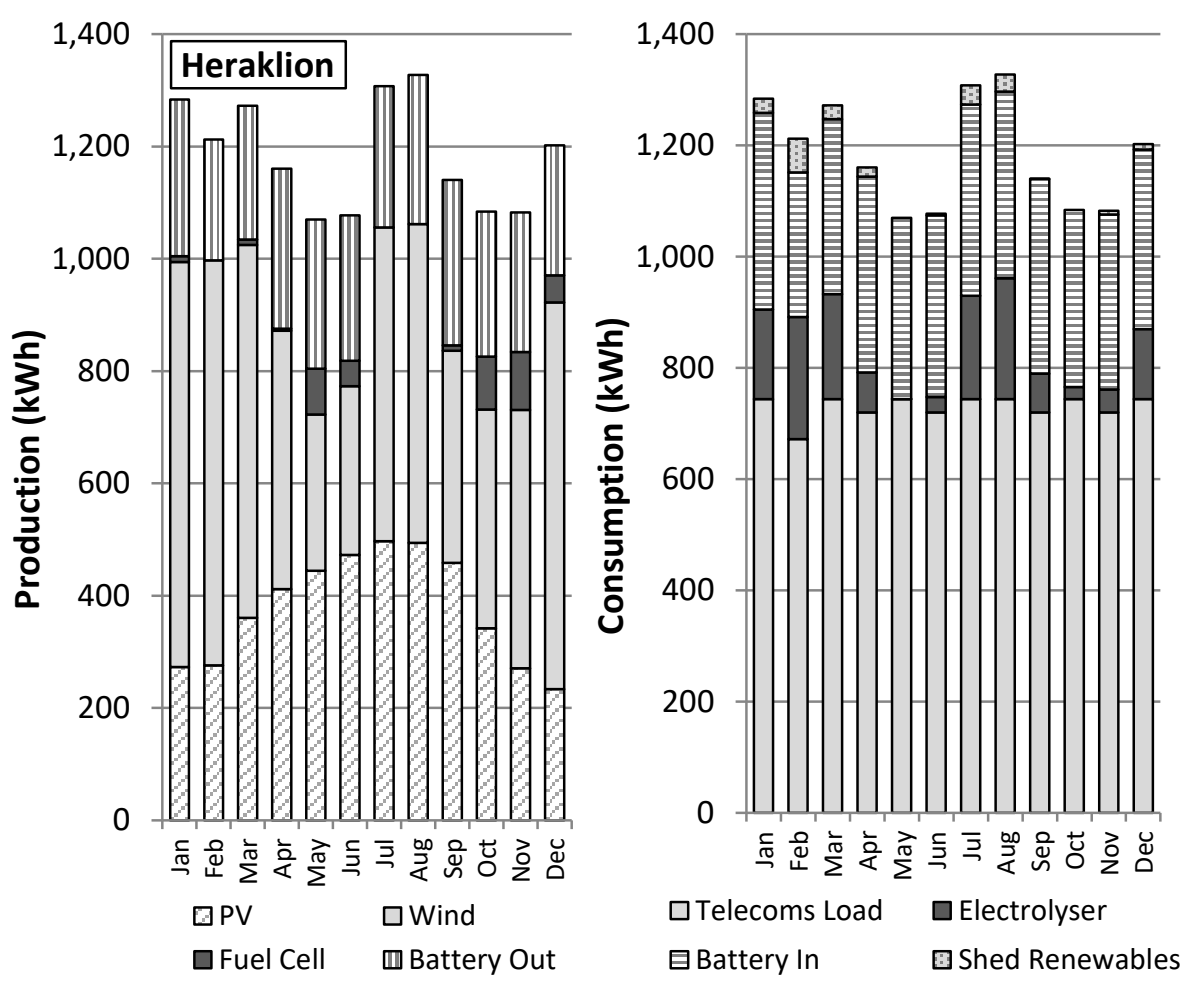

451 Figure 11: Monthly variations in electricity production and consumption (Heraklion)

\section{Conclusions}

This analysis has shown that a combination of hydrogen and battery technologies in a hybrid configuration can provide power continuously for a telecom load from an off-grid PV and/or wind power source. Substantial storage facilities are needed to provide power during lulls in supply from the power source, but the proposed hybrid configurations should enable more reliable and longer-lasting systems than conventional battery-only systems. For the three distinct locations analysed, the identified capacities required for the renewable power source, hydrogen store and battery store vary significantly but the ranges are sufficiently narrow to invite a modular design approach for developing a hybrid system product for global application.

The integration of on-site hydrogen generation and storage enables off-grid renewables to be harnessed more effectively and battery SOC to be much more tightly controlled (so maximizing battery life expectancy and useful capacity despite the inherent temporal variation in the renewable energy supply). The oversizing of PV / wind turbine capacities often needed in battery-only systems to avoid long periods at low SOC can be reduced, as can the wasted renewables encountered during periods of the year with high renewables availability. Only a relatively small electrolyser $(1.6 \mathrm{~kW})$ and fuel cell $(1 \mathrm{~kW})$ are required; the hydrogen store does not lose energy through self-discharge and low states of charge do not adversely affect its life. Hence an electrolyser/store/fuel-cell system can be used to extend battery life (the critical component in off-grid systems) by absorbing the seasonal variation in renewable supply and allowing the batteries to cycle within their optimal SOC range year-round. This separation of conversion and storage components means that storage capacity, unlike for batteries, can be increased without the need to resize the electrolyser and fuel cell. The hydrogen system also helps ensure telecom reliability by providing temporary backup power in case of failure of the PV, wind or battery components. Hydrogen storage levels can be measured accurately remotely to provide precise estimates of remaining runtime, whereas 
battery SOC can be difficult to measure accurately. Also the decreased requirement for batteries relative to a battery-only system reduces the use of battery chemicals, many of which are toxic.

Within a hybrid system, the high round-trip efficiency of batteries makes them suitable for daily cycling, particularly in PV-powered systems with no overnight supply. They improve system efficiency and hence reduce the PV/wind power capacities that would otherwise be required by a hydrogen-only system. Also the battery store acts to reduce the number of electrolyser / fuel cell start-ups, absorbs transients and it is more compact than a hydrogen storage facility. Hybrid systems are more efficient than diesel generators, do not require regular deliveries of diesel (or hydrogen), respond rapidly to the varying output of renewables, and operate readily at the low loads frequently encountered with PV/wind power sources with increased rather than reduced efficiency. However, it should be noted that any variation in the assumed steady load of the application (e.g. due to seasonal weather variations) may require an adjustment of component sizes.

The hybrid hydrogen-battery concept has been analysed by developing and using an hourly model to investigate the sizing and operation of a PV-powered system (Phoenix), a wind-powered system (Reykjavik) and a combined PV and wind-powered system (Heraklion). When compared with a batteryonly system, the hydrogen technologies serve to maintain a high SOC year-round, irrespective of the temporal variations in renewable power generation, and to substantially reduce the number of batteries required. The role of the hydrogen component is to extend battery life by managing the SOC level by on both short term and long term timescales. This ability is very advantageous in locations with a high seasonal variation (e.g. Reykjavik) where battery-only systems otherwise need to survive six months without a full charge, but also in PV-powered systems which experience daily battery cycling due to the lack of overnight supply, and benefit from performing this cycling at high SOC. Where feasible a dual PV/wind-powered hybrid system can smooth renewable electricity generation throughout the year, which results in reduced capacity requirements for hydrogen storage and renewable power sources. Finally, when compared with delivered hydrogen solutions, the carbon footprint of the proposed hybrid approach is very attractive because it is based entirely on renewable energy - this is most important in the context of decarbonising energy use in the telecom sector. 


\section{Appendix A: Subtracting Compressor Work from Electrolyser Power}

The model accounted for the compressor work as follows.

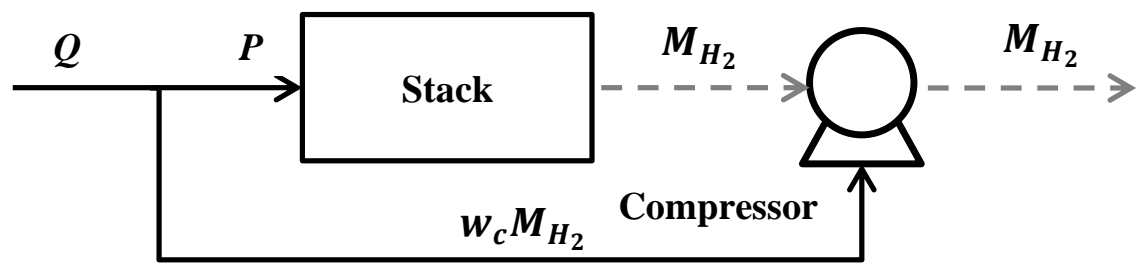

The energy required to operate the compressor was subtracted from the system power $Q$ sent for electrolysis before the remainder $P$ was sent to the electrolyser stack, i.e.

$$
P=Q-3,600 w_{c} M_{H_{2}}
$$

where $M_{\mathrm{H} 2}$ is the mass flowrate of hydrogen produced by the electrolyser $\left(\mathrm{kg} \mathrm{s}^{-1}\right)$, the compressor work $W_{\mathrm{c}}$ is $4.35 \mathrm{kWh} \mathrm{kg}^{-1}$ and $P$ and $Q$ are measured in $\mathrm{kW}$. The model here considered the compressor to operate continuously; in practice a buffer tank could be used to allow intermittent compression up to the high-pressure tank. $M_{\mathrm{H} 2}$ can be found from the electrolyser stack efficiency $\eta$ (electrolyser BOP drain is low enough to be ignored here), stack power $P$ and the Higher Heating Value (HHV) of hydrogen (141.8 $\mathrm{MJ} / \mathrm{kg})$ :

$$
M_{H_{2}}=\frac{\eta}{1,000 H H V} P
$$

Stack efficiency $\eta$ is related to the stack voltage $V$ by:

$$
\eta=\frac{E^{0}}{V}
$$

where $E^{0}$ is the thermoneutral stack voltage ( $8.88 \mathrm{~V}$ for a stack with six cells). Here the stack voltage is taken to be related to the stack current through a simple linear relationship (Figure 2); a reasonable approximation across most of the operating range, except for a slight under-prediction of current at low voltages. Hence the stack power $P$ can be written as:

$$
\begin{gathered}
P=\frac{V I}{1000} \\
P=(a V+b) V
\end{gathered}
$$

where the values of $a$ and $b$ for the current-voltage relationship in Figure 2 are $0.05 \mathrm{~kW} \mathrm{~V}^{-2}$ and $-0.456 \mathrm{~kW}$ $\mathrm{V}^{-1}$ respectively. This gives four equations for the four unknowns $\eta, P, M_{\mathrm{H} 2}$ and $V . M_{\mathrm{H} 2}$ can be eliminated from (A. 1)Error! Reference source not found. and (A. 2) to give:

$$
P=\frac{Q}{1+\frac{3.6 w_{C}}{H H V} \eta}
$$

Eliminating $V$ from (A. 3) and (A. 4), 
537

538

539

540

541

542

543

544

545

546

547

548

549

550

551

552

553

554

555

$$
P=\left(a \frac{E^{0}}{\eta}+b\right) \frac{E^{0}}{\eta}
$$

$P$ can be eliminated from (A. 5) and (A. 6) to give:

$$
\frac{Q}{1+\lambda \eta}=\left(a E^{0}+b \eta\right) \frac{E^{0}}{\eta^{2}}
$$

where, for convenience,

$$
\lambda=\frac{3.6 w_{c}}{H H V}
$$

This yields a quadratic for $\eta$, which can be solved to give:

$$
\eta=\frac{-\left(a E^{0^{2}} \lambda+b E^{0}\right)+\sqrt{\left(a E^{0^{2}} \lambda+b E^{0}\right)^{2}-4 a E^{0^{2}}\left(b E^{0} \lambda-Q\right)}}{2\left(b E^{0} \lambda-Q\right)}
$$

The stack efficiency $\eta$ is plotted vs. stack power $P$ as shown in Figure 2, increasing at part-load from 75\% at a stack power of $1.6 \mathrm{~kW}$. To determine the effect of compressor work on system performance, the system efficiency $\mu$ is defined as:

$$
\mu=\frac{P \eta}{Q}
$$

This yields the following expression for $\mu$ :

$$
\mu=\frac{-\left(a E^{0^{2}} \lambda-b E^{0}\right)+\sqrt{\left(a E^{0^{2}} \lambda-b E^{0}\right)^{2}-4 a E^{0^{2}} Q}}{2 Q}
$$

This is plotted $v$ s. system power $Q$ in Figure 2, and is about $70 \%$ at a system power of $1.6 \mathrm{~kW}$ (note the corresponding stack power $P$ is less than this), rising as system power falls. System efficiency continues to increase as system power decreases because the power used for compression decreases as the hydrogen flowrate decreases. 
[1] International Energy Agency, "Technology Roadmap: Solar Photovoltaic Energy," Paris, 2014.

[2] International Energy Agency, "Africa Energy Outlook," Paris, 2014.

[3] Fuel Cell Today, "Fuel Cells and Hydrogen in China," 2012.

[4] W. Margaret Amutha and V. Rajini, "Techno-economic evaluation of various hybrid power systems for rural telecom," Renewable and Sustainable Energy Reviews, vol. 43, p. 553-561, 2015.

[5] G. Bruni, S. Cordiner, V. Mulone, A. Giordani, M. Savino, G. Tomarchio, T. Malkow, G. Tsotridis, S. Bodker, J. Jensen, R. Bianchi and G. Picciotti, "Fuel cell based power systems to supply power to Telecom Stations," International Journal of Hydrogen Energy, vol. 39, no. 36, p. 21767-21777, 2014.

[6] K.-A. Adamson and C. Wheelock, "Off-Grid Power for Mobile Base Stations," Navigant Consulting, Inc, 2013.

[7] R. Wagner, "Chapter 7 - Stationary applications. I. Lead-acid batteries for telecommunications and UPS," in Industrial Applications of Batteries, M. Broussely and G. Pistoia, Eds., Amsterdam, Elsevier B.V., 2007, p. 395-454.

[8] S. S. Misra, "Advances in VRLA battery technology for telecommunications," Journal of Power Sources, vol. 168, no. 1, p. 40-48, 2007.

[9] E. Varkaraki, N. Lymberopoulos and A. Zachariou, "Hydrogen based emergency back-up system for telecommunication applications," Journal of Power Sources, vol. 118, no. 1-2, p. 14-22, 2003.

[10] Fuel Cell Today, "First Sale of Acta's Integrated Fuel Cell-Electrolyser Backup Power System," 28 May 2013.

[11] International Energy Agency, "Photovoltaic Power System Programme Implementing Agreement on Photovoltaic Power Systems: Task 3 - Testing of batteries used in stand-alone PV power supply systems. Report IEA PVPS T3-11," IEA PVPS, Paris, 2002.

[12] J. Runyon, "Keeping up with energy storage," Renewable Energy World, vol. 17, no. 4, pp. 60-68, 2014.

[13] J. Schiffer, D. U. Sauer, H. Bindner, T. Cronin, P. Lundsager and R. Kaiser, "Model prediction for ranking lead-acid batteries according to expected lifetime in renewable energy systems and autonomous power-supply systems," J. Power Sources, vol. 168, no. 1, p. 66-78, 2007. 
[14] S. Hua, Q. Zhou, D. Kong and J. Ma, "Application of valve-regulated lead-acid batteries for storage of solar electricity in stand-alone photovoltaic systems in the northwest areas of China," Journal of Power Sources, vol. 158, no. 2, p. 1178-1185, 2006.

[15] R. Kaiser, "Optimized battery-management system to improve storage lifetime in renewable energy systems," Journal of Power Sources, vol. 168, no. 1, p. 58-65, 2007.

[16] D. P. Jenkins, J. Fletcher and D. Kane, "Lifetime prediction and sizing of lead-acid batteries for microgeneration storage applications," IET Renewable Power Generation, vol. 2, no. 3, pp. 191200, 2008.

[17] G. Gómez, G. Martínez, J. L. Gálvez, R. Gila, R. Cuevas, J. Maellas and E. Bueno, “Optimization of the photovoltaic-hydrogen supply system of a stand-alone remote-telecom application," International Journal of Hydrogen Energy, vol. 34, no. 13, p. 5304-5310, 2009.

[18] D. Bezmalinović, F. Barbir and I. Tolj, "Techno-economic analysis of PEM fuel cells role in photovoltaic-based systems for the remote base stations," International Journal of Hydrogen Energy, vol. 38, no. 1, p. 417-425, 2013.

[19] S. Jiménez-Fernández, S. Salcedo-Sanz, D. Gallo-Marazuela, G. Gómez-Prada, J. Maellas and A. Portilla-Figueras, "Sizing and maintenance visits optimization of a hybrid photovoltaic-hydrogen stand-alone facility using evolutionary algorithms," Renewable Energy, vol. 66, p. Pages 402-413, 2014.

[20] J. L. Bernal-Agustín and R. Dufo-López, "Simulation and optimization of stand-alone hybrid renewable energy systems," Renewable and Sustainable Energy Reviews, vol. 13, no. 8, p. 21112118, 2009.

[21] P. Bajpai and V. Dash, "Hybrid renewable energy systems for power generation in stand-alone applications: A review," Renewable and Sustainable Energy Reviews, vol. 16, no. 5, p. 2926-2939, 2012.

[22] A. Chauhan and R. P. Saini, "A review on integrated renewable energy system based power generation for stand-alone applications: configurations, storage options, sizing methodologies and control," Renewable and Sustainable Energy Reviews, vol. 38, p. 99-120, 2014.

[23] M. Bielmann, U. F. Vogt, M. Zimmermann and A. Züttel, "Seasonal energy storage system based on hydrogen for self sufficient living," J. Power Sources, vol. 196, p. 4054, 2011.

[24] B. Shabani and J. Andrews, "Standalone solar-hydrogen systems powering Fire Contingency Networks," International Journal of Hydrogen Energy, vol. 40, no. 15, pp. 5509-5517, 2015. 
[25] P. García, J. P. Torreglosa, L. M. Fernández and F. Jurado, "Improving long-term operation of power sources in off-grid hybrid systems based on renewable energy, hydrogen and battery," Journal of Power Sources, vol. 265, p. 149-159, 2014.

[26] F. Zhang, K. Thanapalan, A. Procter, S. Carr, J. Maddy and G. Premier, "Power management control for off-grid solar hydrogen production and utilisation system," International Journal of Hydrogen Energy, vol. 38, no. 11, p. 4334-4341, 2013.

[27] S. G. Tesfahunegn, $\varnothing$. Ulleberg, P. J. S. Vie and T. M. Undeland, "Optimal shifting of PV and load fluctuations from fuel cell and electrolyzer to lead acid battery in a PV-H2 standalone power system for improved performance and life time," J Power Sources, vol. 196, p. 10401, 2011.

[28] Future-E, "Future-E Fuel Cell Systems: Jupiter Product Family," [Online]. Available: http://futuree.de/data/mediapool/futuree_jupiter_family_dina4-4k-rgb.pdf. [Accessed April 2015].

[29] D. Scamman, H. Bustamante, S. Hallett and M. Newborough, "Off-grid solar-hydrogen generation by passive electrolysis," International Journal of Hydrogen Energy, vol. 39, no. 35, p. 19855-19868, 2014.

[30] “Hybrid Optimization Model for Electric Renewables," [Online]. Available: http://www.homerenergy.com. [Accessed 18 December 2013].

[31] NASA, "Surface meteorology and Solar Energy (SSE)," Prediction of Worldwide Energy Resource Project (POWER), [Online]. Available: https://eosweb.larc.nasa.gov/sse/. [Accessed 18 December 2013].

[32] Wind \& Sun Ltd, "Proven Wind Turbines," [Online]. Available: http://windsunweb.demonweb.co.uk/Wind/wind_proven.htm. [Accessed April 2015].

[33] M. New, D. Lister, M. Hulme and I. Makin, "A high-resolution data set of surface climate over global land areas," Climate Research, vol. 21, pp. 1-25, 2000.

[34] Rolls Battery, "4KS25P Flooded Deep Cycle Battery," [Online]. Available: http://rollsbattery.com/public/specsheets/4KS25P.pdf. [Accessed April 2015]. 